Review Article

\title{
Main Risk Factors of Type 2 Diabetes Mellitus with Nonalcoholic Fatty Liver Disease and Hepatocellular Carcinoma
}

\author{
Yueying Qi, ${ }^{1}$ Lirong Fan, ${ }^{2}$ Decong Ran, ${ }^{3}$ Jieda $\mathrm{Xu},{ }^{4}$ Yuansong Wang, ${ }^{5}$ Jin $W u,{ }^{5}$ \\ and Zhongyong Zhang ${ }^{5}{ }^{5}$ \\ ${ }^{1}$ Department of Gastroenterology and Hepatology, Cangzhou Hospital of Integrated Traditional Chinese Medicine and \\ Western Medicine, 31 West Huanghe Road, Cangzhou, Hebei, China \\ ${ }^{2}$ Department of Endocrinology, The Traditional Chinese Medicine Hospital of Botou, West Shengli Road, Botou, Hebei, China \\ ${ }^{3}$ Graduate School, Hebei University of Chinese Medicine, Xingyuan Road, Shijiazhuang, Hebei, China \\ ${ }^{4}$ Graduate School, Chengde Medical University, Anyuan Road, Chengde, Hebei, China \\ ${ }^{5}$ Department of Endocrinology, Hebei Province Cangzhou Hospital of Integrated Traditional Chinese Medicine and \\ Western Medicine, 31 West Huanghe Road, Cangzhou, Hebei, China
}

Correspondence should be addressed to Zhongyong Zhang; jiuzai63879572419@163.com

Received 1 July 2021; Accepted 15 September 2021; Published 13 October 2021

Academic Editor: Muhammad Wasim Khan

Copyright (c) 2021 Yueying Qi et al. This is an open access article distributed under the Creative Commons Attribution License, which permits unrestricted use, distribution, and reproduction in any medium, provided the original work is properly cited.

Type 2 diabetes mellitus (T2DM) with nonalcoholic fatty liver disease (NAFLD) is a pathological metabolic disease characterized by high ketone lipid based on abnormal lipid metabolism. Compared with patients with single T2DM or NAFLD, T2DM complicated with NAFLD has more complicated pathogenic factors and pathological processes. Hepatocellular carcinoma (HCC), the leading malignancy arising from cirrhosis, is the second most lethal cancer globally. The purpose of this study was to clarify the main risk factors of T2DM with NAFLD and HCC. There are many challenges in the diagnosis and treatment of T2DM patients with NAFLD and HCC. The current gold standard is to adjust treatment strategy, optimize metabolic control, and improve liver phenotype. It is necessary to identify further the risk factors driving the progression of T2DM with NAFLD and HCC and evaluate new therapeutic targets, in addition to exploring the syndromic forms of T2DM combined with NAFLD and providing a theoretical basis for early prevention, diagnosis, and treatment of the disease using traditional Chinese medicine (TCM).

\section{Introduction}

Nonalcoholic fatty liver disease (NAFLD) is prevalent in patients with type 2 diabetes mellitus (T2DM) [1]. Previous studies had shown that $50 \%$ of T2DM patients had NAFLD, while the incidence of NAFLD in obese diabetic patients is as high as $100 \%$ [2]. There is increasing evidence that patients with T2DM have a particularly high risk of developing nonalcoholic fatty liver disease, nonalcoholic steatohepatitis, and hepatocellular carcinoma (HCC) [3]. HCC is a major life-limiting factor in progressive fibrotic liver disease, mainly caused by a chronic viral infection, alcohol abuse, and nonalcoholic fatty liver disease [4].
In prospective studies, preexisting diabetes mellitus was an independent risk factor for NAFLD progression and liver-related mortality $[5,6]$. Studies had shown that the existence of NAFLD predicted the development of T2DM [7]. A cross-sectional study of T2DM patients found that the prevalence of NAFLD identified by ultrasound was 69\% [8]. In a Swedish cohort study, most NAFLD patients (78\%) were diagnosed with diabetes or impaired glucose tolerance at follow-up [9]. In addition, the interaction of environmental and genetic factors can promote the progress of T2DM with NAFLD. NAFLD increased the incidence of T2DM. At the same time, T2DM can effectively accelerate the development of NAFLD to a more serious form. In most developed 
countries, NAFLD is currently the most common liver disease and a major risk factor for HCC [10]. One study showed that diabetes increases the risk of HCC [11]. Whether the interaction between diabetes and the etiology of cirrhosis affects the risk of liver cancer remains controversial.

Although significant progress has been made in discovering new targets and treating chronic liver disease in recent decades, most treatment methods have not achieved satisfactory results [12]. Traditional Chinese medicine (TCM) treatment of the disease has the advantages of stable curative effect, safety, being nontoxic, low price, and multitarget effect [13]. In particular, the TCM syndrome types of different diseases may suggest different TCM treatment schemes.

\section{Epidemiology of T2DM}

The International Diabetes Federation estimates that 371 million adults worldwide had diabetes [14]. In China, the prevalence of diabetes reached $11.6 \%$ in 2010, affecting about 113.9 million adults [15]. It is estimated that, by 2040, about 642 million people will have diabetes, and T2DM is the main type of diabetes [16]. T2DM had become a heavy burden of limited medical resources. Since 1980, the incidence rate and prevalence of T2DM in the world had increased two times, and they are still increasing [17]. It had been reported that the prevalence of T2DM in women was on the rise globally, which was more common in low-income countries where obesity and aging were seen as driving forces [18]. In the United States, about one-third of patients with T2DM are adolescents [19]. It is estimated that the prevalence of T2DM in the population above 20 years of age ranges from $6.6 \%$ to $7.0 \%$ in Spain and 6.3\% in Midi-Pyrénées, while the estimated value in men in these three regions is about more than $2 \%[20]$.

\section{Epidemiology of NAFLD}

NAFLD can be divided into two categories: primary and secondary. Fatty liver associated with metabolic syndrome caused by excess nutrition and cryptogenic fatty liver belongs to the category of primary nonalcoholic fatty liver disease. Fatty liver caused by malnutrition, total parenteral nutrition, drug/environment, and industrial toxicosis belongs to the category of secondary nonalcoholic fatty liver disease. NAFLD refers to all kinds of liver diseases, such as nonalcoholic steatohepatitis (NASH), simple steatosis (NAFL), and fibrosis. The incidence rate of NAFLD is expected to increase worldwide with the increase of obesity and diabetes. Recently, studies concluded that the prevalence of NAFLD worldwide is $25.2 \%$, and the prevalence of NAFLD in the US is expected to increase by $50 \%$ by $2030[21,22]$. The prevalence of NAFLD in China was about 20\% [23]. NAFLD patients had not only a risk of progressive liver disease but also a significantly increased risk of cancer death [24]. NAFLD is diagnosed when more than $5 \%$ of liver cells show fat accumulation or by histological or imaging evaluation
[25]. The pathogenesis of NAFLD is complex and has not been fully elucidated.

\section{Epidemiology of HCC}

Liver cancer mainly refers to malignant tumors originating from hepatocytes, liver epithelium, or liver mesenchymal tissue. HCC is more specific, mainly hepatocellular carcinoma. The etiology of the two cancers is also slightly different. Hepatocellular carcinoma is mainly caused by hepatitis B and hepatitis C. HCC accounts for $>80 \%$ of primary liver cancers worldwide [26]. HCC accounted for $72.7 \%$ of global deaths in 2015 [27]. In addition, the World Health Organization (WHO) estimates that more than 1 million patients are expected to die from liver cancer within the next 10 years [28]. The incidence of liver cancer varies geographically, with the majority of liver cancer cases occurring in less developed regions, such as East Asia (54.8\% of cases) and Southeast Asia (10.8\% of cases) [29]. From 2006 to 2017, the incidence of HCC increased by $2-3 \%$ per year, mainly due to viral cirrhosis and a high incidence of NAFLD [30].

\section{Main Risk Factors of T2DM with NAFLD}

5.1. Genetic Factors. TM6SF2rs 58542926 mutation was closely related to NAFLD, age, body mass index (BMI), and T2DM [31]. TM6SF2 is located in ER and Golgi complex and has the function of mobilizing neutral lipids for VLDL assembly. In the absence of lipid droplets, lipids accumulate in the droplets [32]. However, the assessment of insulin resistance (IR) or oral glucose tolerance test did not reduce in the TM6SF2 gene mutation vector [33]. Therefore, the mutation may not be associated with IR.

Not only is PNPLA 3 gene mutation related to NAFLD, but also it has a slightly increased risk of T2DM $[34,35]$. In fact, the expression of PNPLA 3 is directly regulated by the insulin regulatory transcription factor sterol regulatory element-binding protein 1c (SREBP-1c). In the case of obesity and IR, the accumulation of pathogenic PNPLA 3 mutation products aggravates liver steatosis, inflammation, and cirrhosis [36].

Adiponectin (HMW) is an adipocytokine and insulinsensitive substance, which plays an essential role in the pathogenesis of diabetes mellitus and NAFLD [37]. HMWrs 266729 polymorphism is associated with an increased risk of NAFLD patients [38]. Studies on different populations showed that HMW gene polymorphism affected the development of NAFLD [39, 40]. There was a significant correlation between rs1501299 and NAFLD in some female diabetic patients in Japan [41]. HMW is considered a potential biomarker for the detection and prediction of NAFLD complicated with T2DM [42]. Lu et al. found that the mutation frequency of LEPR nucleotide $3057 \mathrm{G}>\mathrm{A}$ (rs1805096) was $76.0 \%$ in 104 T2DM patients with NAFLD. The results suggested that LEPR gene G3057 A (rs1805096) polymorphism may be involved in NAFLD by regulating lipid metabolism and affecting insulin sensitivity in patients with T2DM [43]. 
5.2. Insulin Resistance. The close relationship between NAFLD and T2DM is that they have common pathogenesis, namely, IR [44]. IR refers to the decrease of tissue response to insulin [45]. The pathogenesis of NAFLD is described as the "multiple hit hypothesis." IR plays a central role in the first attack, resulting in an imbalance between factors that promote liver fat accumulation and factors that prevent fatty acid accumulation $[46,47]$. The steady-state model assessment value of $\beta$ cell function and the decreased value of $\beta$ cell function in patients of T2DM with NAFLD were higher than those in patients without NAFLD, including IR of liver and adipocytes [48]. Therefore, NAFLD often coexists with T2DM.

Swollen and inflamed visceral adipose tissue is likely to trigger various factors that may be correlated with the development of IR and NAFLD, such as inflammatory adipocytokines and free fatty acids [49]. The interaction between hepatic steatosis and IR establishes a circle to promote the development of T2DM and NAFLD. In addition, glucose cotransporter 2 can promote renal reabsorption of glucose and reduce urinary glucose excretion by increasing blood glucose and body weight (BW), thus aggravating IR in T2DM and NAFLD patients [50]. This relationship between T2DM, IR, and NAFLD is believed to be due to insulin being delivered directly to the portal vein after secretion in the same way as glucose absorbed. IR plays a crucial role in the pathogenesis of T2DM with NAFLD. Therefore, insulin sensitizer is considered as an effective treatment.

5.3. Lifestyle. A multicenter clinical trial involving 5145 overweight adults with T2DM showed that, after 12 months of intensive lifestyle intervention, steatosis and NAFLD were significantly reduced, and weight loss was at least 7\% [51]. Recent randomized controlled trials $(n=154)$ had again shown that lifestyle intervention could effectively alleviate NAFLD in nonobese and obese patients [52]. Numerous studies have shown that developing a reasonable exercise plan is significant for alleviating T2DM and NAFLD. Reasonable exercise plays an important role in controlling the blood sugar and blood lipids of patients and can significantly improve the therapeutic effect of T2DM or NAFLD.

The relationship between diet and T2DM with NAFLD is very complex. Excess of total energy intake can lead to obesity by changing the energy balance. A high carbohydrate diet (50\% to $65 \%$ of carbohydrate calories) is associated with IR and obesity [53]. All of these are risk factors for damaging NAFLD phenotype and increasing IR [25]. A review study evaluated the effects of probiotics and synbiotics on obesity, T2DM, and NAFLD [54]. The beneficial effects of probiotics and synbiotics improved liver function and metabolic parameters in NAFLD patients.

Lower frequency and level of physical activity and being sedentary for a long time were associated with IR, T2DM, and NAFLD. Sedentary behavior is associated with chronic low-grade inflammation and can lead to obesity [55]. Exercise management can prevent or delay the progress of T2DM [56]. Among large numbers of middle-aged Korean people, being sedentary and reduced physical activity are positively correlated with the prevalence of NAFLD, which supports the importance of increasing physical activity to promoting physical activity $[57,58]$.

5.4. Obesity. Obesity is a chronic metabolic disease, which is mainly characterized by excessive accumulation of fat and overweight. The current research showed that the causes of obesity are diverse, and the main reasons are divided into congenital factors and exogenous factors. Studies have shown that the congenital factors of obesity are mainly genetic factors, while the exogenous factors are mainly excessive diet, lack of exercise, or pathological obesity.

The incidence rate of obesity and its metabolic complications worldwide had risen sharply in recent years. Obesity is an important risk factor for NAFLD and T2DM and may provide a common link through IR [59]. Recent studies had shown that obesity (whether peripheral or central obesity) usually preceded NAFLD, and NAFLD preceded the development of T2DM [60]. Obesity is closely related to adipose tissue dysfunction in NAFLD patients, which may accelerate IR and pancreatic $\beta$ cell dysfunction [61]. To a large extent, IR in obese patients is the result of adipose tissue inflammation and adipocyte regulation disorder [62]. Weight loss has a significant effect on T2DM with NAFLD, and the weight loss is mainly due to the reduction of fat mass, especially visceral fat, rather than skeletal muscle mass [63]. Bariatric surgery is an effective method to treat obesity, which has been proved to significantly improve or even cure diabetes and improve the histological characteristics of NAFLD [64].

In addition, a large number of studies have shown that obesity is closely related to the intestinal flora. The change of intestinal microbiota composition has been considered an effective therapy to regulate obesity [65].

5.5. Others. The data showed that NAFLD and diabetes were related to the decrease of CYP3A4 activity in the liver [66]. In human studies, low plasma adiponectin levels are associated with an increased risk of T2DM, and low adiponectin levels are an independent risk factor for NAFLD [67]. In addition, LDL-c, FPG, BMI, FINS, TC, and HOMA-IR were also risk factors of T2DM with NAFLD [44]. In 146 T2DM patients with NAFLD, multivariate analysis showed that dyslipidemia, elevated $\mathrm{LDL}, \mathrm{HbA1c}$, and diastolic blood pressure were risk factors [68]. In addition, human and animal intestines are occupied by a variety of microorganisms. These microorganisms play a key role in maintaining intestinal function and regulating host immune response and chronic diseases such as obesity, diabetes, and NAFLD [69-71].

\section{Main Risk Factors of HCC}

Major risk factors contributing to the rise in HCC include high prevalence of HBV and HCV infection, followed by an increased incidence of alcohol abuse, obesity, NAFLD, and 
TABLE 1: Studies which have evaluated the association between type 2 diabetes and risk of HCC.

\begin{tabular}{|c|c|c|c|c|}
\hline Study & Study characteristics & Diabetes diagnosis & $\begin{array}{l}\text { Covariate adjustment } \\
\text { considered }\end{array}$ & Main findings \\
\hline $\begin{array}{l}\text { Huo et al., Eur J } \\
\text { Gastroenterol Hepatol } \\
2003 ; 15: 1203-8\end{array}$ & $\begin{array}{c}\text { Prospective study: } 239 \text { HCC } \\
\text { patients (16.3\% of whom } \\
\text { had DM). Mean follow-up: } \\
2.6 \text { years }\end{array}$ & $\begin{array}{l}\text { Fasting glucose } \\
\geq 126 \mathrm{mg} / \mathrm{dL} \text { or } 2 \text { - } \\
\text { hour postload } \\
\text { glucose } \geq 200 \mathrm{mg} / \mathrm{dL} \text {, } \\
\text { or past history }\end{array}$ & $\begin{array}{l}\text { Age, sex, tumor size, anti- } \\
\text { HCV-Ab positivity, HBeAg- } \\
\text { positivity, cirrhosis, alcohol } \\
\text { intake, alpha-fetoprotein, } \\
\text { albumin, bilirubin }\end{array}$ & $\begin{array}{l}\text { DM did not affect long- } \\
\text { term survival in HCV- } \\
\text { related HCC but was a } \\
\text { recurrence-independent } \\
\text { prognostic factor for HBV- } \\
\text { related HCC }\end{array}$ \\
\hline $\begin{array}{l}\text { Coughlin et al., Am J } \\
\text { Epidemiol 2004; 159: } \\
1160-7\end{array}$ & $\begin{array}{l}\text { Population cohort study: } \\
467,922 \text { men and } 588,321 \\
\text { women without history of } \\
\text { cancer at baseline. Mean } \\
\text { follow-up: } 16 \text { years }\end{array}$ & Self-reported & BMI & $\begin{array}{l}\mathrm{DM} \text { was associated with } \\
\text { increased risk of incident } \\
\text { HCC only in men }\end{array}$ \\
\hline $\begin{array}{l}\text { El-Serag et al., } \\
\text { Gastroenterology } \\
2004 ; 126: 460-8\end{array}$ & $\begin{array}{l}\text { Prospective study: } 73,643 \\
\text { patients with DM and } \\
650,620 \text { patients without } \\
\text { DM. Mean follow-up: } 5 \\
\text { years }\end{array}$ & Self-reported & $\begin{array}{c}\text { Alcoholic liver disease, viral } \\
\text { chronic hepatitis, } \\
\text { demographic variables }\end{array}$ & $\begin{array}{l}\text { DM was associated with an } \\
\text { increased risk of incident } \\
\text { HCC. DM carried the } \\
\text { highest risk among patients } \\
\text { with a follow-up longer } \\
\text { than } 10 \text { years }\end{array}$ \\
\hline $\begin{array}{l}\text { Davilla et al., Gut } \\
2005 ; 54: 533-9\end{array}$ & $\begin{array}{c}\text { Population-based case- } \\
\text { control study: } 2,061 \mathrm{HCC} \\
\text { patients (of whom } 43 \% \text { with } \\
\text { DM) and 6,183 noncancer } \\
\text { controls (of whom } 19 \% \text { with } \\
\text { DM) }\end{array}$ & Electronic register & $\begin{array}{l}\text { Age, sex, race, } \mathrm{HCV}, \mathrm{HBV}, \\
\text { alcoholic liver disease, and } \\
\text { hemochromatosis }\end{array}$ & $\begin{array}{l}\text { DM was associated with a } \\
\text { nearly threefold increased } \\
\text { risk of HCC }\end{array}$ \\
\hline $\begin{array}{l}\text { Inoue et al., Arch } \\
\text { Intern Med 2006; } 166 \text { : } \\
\text { 1871-7 }\end{array}$ & $\begin{array}{c}\text { Prospective study: } 97,771 \\
\text { Japanese adult individuals } \\
\text { followed up for cancer } \\
\text { incidence over } 5 \text { years. At } \\
\text { baseline, } 4.7 \% \text { of them had } \\
\text { DM }\end{array}$ & Self-reported & $\begin{array}{l}\text { Age, study area, BMI, prior } \\
\text { cardiovascular disease, } \\
\text { smoking, alcohol intake, } \\
\text { leisure-time physical activity, } \\
\text { green vegetable intake, coffee } \\
\text { intake }\end{array}$ & $\begin{array}{l}\text { DM was associated with } \\
\text { increased risk of total } \\
\text { cancer and cancer in } \\
\text { specific sites, including } \\
\text { HCC }\end{array}$ \\
\hline $\begin{array}{l}\text { El-Serag et al. Clin } \\
\text { Gastroenterol Hepatol } \\
\text { 2006; } 4: 369-80\end{array}$ & $\begin{array}{l}\text { Meta-analysis: a total of } 26 \\
\text { studies (of which } 13 \text { were } \\
\text { case-control studies and } 13 \\
\text { were cohort studies), } \\
\text { inclusive of approximately } 3 \\
\text { million individuals }\end{array}$ & Self-reported & $\begin{array}{l}\text { Alcohol intake, chronic viral } \\
\text { hepatitis, diet, BMI }\end{array}$ & $\begin{array}{l}\text { Among } 13 \text { cohort studies, } \\
\text { DM was associated with an } \\
\text { increased risk of HCC }\end{array}$ \\
\hline $\begin{array}{l}\text { Kawamura et al., J } \\
\text { Gastroenterol Hepatol } \\
2008 ; 23: 1739-46\end{array}$ & $\begin{array}{c}\text { Prospective study: } 40 \\
\text { consecutive HCC patients } \\
\text { (with HCC associated with } \\
\text { non-B, non-C hepatitis) and } \\
\text { later underwent surgical } \\
\text { resection or radiofrequency } \\
\text { ablation. Prevalence of DM } \\
\text { was } 45 \% \text {. Mean follow-up: } 5 \\
\text { years }\end{array}$ & $\begin{array}{c}\text { Fasting glucose } \\
\geq 126 \mathrm{mg} / \mathrm{dL} \text { or past } \\
\text { history }\end{array}$ & $\begin{array}{l}\text { Age, sex, dyslipidemia, } \\
\text { smoking, alcohol intake, } \\
\text { history of blood transfusion, } \\
\text { state of liver disease (chronic } \\
\text { hepatitis or cirrhosis), AST, } \\
\text { albumin, bilirubin, alpha- } \\
\text { fetoprotein, prothrombin } \\
\text { time, tumor size, multiplicity, } \\
\text { hypervascularity, and portal } \\
\text { vein invasion of HCC }\end{array}$ & $\begin{array}{l}\text { DM was a significant } \\
\text { predictor of tumor } \\
\text { recurrence after potentially } \\
\text { curative therapy for HCC }\end{array}$ \\
\hline $\begin{array}{l}\text { Donadon et al., World } \\
\text { J Gastroenterol 2009; } \\
15: 2506-11\end{array}$ & $\begin{array}{l}\text { Case-control study: } 465 \\
\text { HCC patients, } 618 \text { with } \\
\text { cirrhosis, and } 490 \text { control } \\
\text { subjects. The prevalence of } \\
\text { DM was } 31.2 \% \text { in HCC, } \\
23.3 \% \text { in cirrhotic patients, } \\
\text { and } 12.7 \% \text { in control group }\end{array}$ & Self-reported & $\begin{array}{l}\text { Age, sex, BMI, alcohol abuse, } \\
\text { HBV, and HCV }\end{array}$ & $\begin{array}{l}\text { DM was an independent } \\
\text { risk factor for HCC. Among } \\
\text { male patients with DM, } \\
\text { there was a positive } \\
\text { association of HCC with } \\
\text { insulin/sulphonylurea } \\
\text { treatment and an inverse } \\
\text { association with metformin }\end{array}$ \\
\hline
\end{tabular}


TABle 1: Continued.

\begin{tabular}{|c|c|c|c|c|}
\hline Study & Study characteristics & Diabetes diagnosis & $\begin{array}{c}\text { Covariate adjustment } \\
\text { considered }\end{array}$ & Main findings \\
\hline $\begin{array}{l}\text { Hassan et al., Cancer } \\
2010 ; 116: 1938-46\end{array}$ & $\begin{array}{l}\text { Hospital-based case-control } \\
\text { study: } 420 \text { patients with } \\
\text { HCC and } 1,104 \text { healthy } \\
\text { controls. The prevalence of } \\
\text { DM was } 33.3 \% \text { in patients } \\
\text { with HCC and } 10.4 \% \text { in } \\
\text { controls }\end{array}$ & Self-reported & $\begin{array}{l}\text { Age, sex, race, educational } \\
\text { level, smoking, alcohol intake, } \\
\text { HCV, HBV, family history of } \\
\text { cancer }\end{array}$ & $\begin{array}{l}\text { DM increased the risk of } \\
\text { HCC. Treatments with } \\
\text { sulfonylureas or insulin } \\
\text { were associated with higher } \\
\text { HCC risk, whereas } \\
\text { treatments with metformin } \\
\text { or glitazones were } \\
\text { associated with lower HCC } \\
\text { risk }\end{array}$ \\
\hline $\begin{array}{l}\text { Hense et al., Diabetol } \\
\text { Metab Syndr 2011; } 3 \text { : } \\
15\end{array}$ & $\begin{array}{l}\text { Community-based study: } \\
26,742 \text { DM patients, who } \\
\text { were } 40 \text { to } 79 \text { years old and } \\
\text { resided in the Muenster } \\
\text { district. Mean follow-up: } 3.3 \\
\text { years }\end{array}$ & Self-reported & $\begin{array}{l}\text { Sex, diabetes duration, BMI, } \\
\text { insulin treatment }\end{array}$ & $\begin{array}{l}\text { Risk of any incident cancer } \\
\text { in DM was increased, in } \\
\text { particular for HCC. Insulin } \\
\text { therapy was related to } \\
\text { higher cancer risk, while } \\
\text { metformin was not }\end{array}$ \\
\hline $\begin{array}{l}\text { Johnson et al., } \\
\text { Diabetologia 2011; } 54 \text { : } \\
2263-71\end{array}$ & $\begin{array}{l}\text { Population-based } \\
\text { retrospective cohort study: } \\
185,100 \text { individuals with } \\
\text { DM and } 185,100 \text { without } \\
\text { DM, matched by sex and } \\
\text { age. Mean follow-up: } 10 \\
\text { years }\end{array}$ & Electronic register & $\begin{array}{l}\text { Age, sex, socioeconomic } \\
\text { status, number of physician } \\
\text { visits, year of diagnosis }\end{array}$ & $\begin{array}{l}\text { DM was associated with } \\
\text { increased risk of selected } \\
\text { cancers, including HCC }\end{array}$ \\
\hline $\begin{array}{l}\text { Li et al., Int J Canc } \\
2012 ; 131: 1197-202\end{array}$ & $\begin{array}{l}\text { Hospital-based case-control } \\
\text { study: } 1,105 \text { patients with } \\
\text { HBV-related HCC and } \\
5,170 \text { patients with chronic } \\
\text { HBV. The whole prevalence } \\
\text { of DM was } 6.7 \%\end{array}$ & $\begin{array}{l}\text { Fasting glucose } \\
\geq 126 \mathrm{mg} / \mathrm{dL} \text { or past } \\
\text { history }\end{array}$ & $\begin{array}{l}\text { Age, family history of HCC, } \\
\text { city of residence, HBV-Ag, } \\
\text { and cirrhosis }\end{array}$ & $\begin{array}{c}\mathrm{DM} \text { was associated with } \\
\text { increased risk of HCC, only } \\
\text { in women }\end{array}$ \\
\hline $\begin{array}{l}\text { Wang et al., Int J } \\
\text { Cancer 2012; } 130 \text { : } \\
\text { 1639-48 }\end{array}$ & $\begin{array}{l}\text { Meta-analysis: a total of } 25 \\
\text { cohort studies, enrolling } \\
\text { 1,283,112 persons. Mean } \\
\text { follow-up: } 8.8 \text { years }\end{array}$ & $\begin{array}{l}\text { Self-report, medical } \\
\quad \text { records }\end{array}$ & $\begin{array}{l}\text { Geographic location, alcohol } \\
\text { intake, history of cirrhosis, or } \\
\text { HBV and HCV infections }\end{array}$ & $\begin{array}{l}\text { DM was associated with } \\
\text { increased risk of incident } \\
\text { HCC and higher HCC } \\
\text { mortality. Longer diabetes } \\
\text { duration and use of } \\
\text { sulfonylureas or insulin } \\
\text { were associated with } \\
\text { increased risk of HCC. } \\
\text { Metformin treatment was } \\
\text { protective }\end{array}$ \\
\hline $\begin{array}{l}\text { Wang et al., Diabetes } \\
\text { Metab Res Rev 2012; } \\
28: 109-22\end{array}$ & $\begin{array}{l}\text { Meta-analysis: } 17 \text { case- } \\
\text { control studies (a total of } \\
\text { nearly 6,000 HCC cases and } \\
74,000 \text { controls) and } 32 \\
\text { cohort studies (a total of } \\
\text { nearly } 6,500,000 \\
\text { individuals) }\end{array}$ & $\begin{array}{l}\text { Self-report, medical } \\
\quad \text { records }\end{array}$ & $\begin{array}{l}\text { BMI, prior hepatitis, cirrhosis, } \\
\text { alcohol intake, smoking, } \\
\text { treatment, duration of } \\
\text { diabetes }\end{array}$ & $\begin{array}{c}\text { The combined risk estimate } \\
\text { of all studies showed a } \\
\text { significant increased risk of } \\
\text { HCC among DM } \\
\text { individuals. In addition, } \\
\text { meta-analysis of } 7 \text { cohort } \\
\text { studies found a significant } \\
\text { increased risk of HCC } \\
\text { mortality for individuals } \\
\text { with DM compared to } \\
\text { those without }\end{array}$ \\
\hline $\begin{array}{l}\text { Lai et al., Am J } \\
\text { Gastroenterol 2012; } \\
107: 46-52\end{array}$ & $\begin{array}{l}\text { Population-based cohort } \\
\text { study: } 19,349 \text { newly } \\
\text { diagnosed DM patients and } \\
77,396 \text { control subjects } \\
\text { without DM. Mean follow- } \\
\text { up: } 5 \text { years }\end{array}$ & Electronic register & $\begin{array}{l}\text { Age, sex, cirrhosis, alcoholic } \\
\text { liver damage, viral hepatitis }\end{array}$ & $\begin{array}{l}\text { DM was associated with } \\
\text { increased risk of incident } \\
\text { HCC. Use of metformin or } \\
\text { glitazones was associated } \\
\text { with reduced HCC risk }\end{array}$ \\
\hline
\end{tabular}


TABLE 1: Continued.

\begin{tabular}{|c|c|c|c|c|}
\hline Study & Study characteristics & Diabetes diagnosis & $\begin{array}{c}\text { Covariate adjustment } \\
\text { considered }\end{array}$ & Main findings \\
\hline $\begin{array}{l}\text { Schlesinger et al., Ann } \\
\text { Oncol 2013; } 24: 2449 \text { - } \\
55\end{array}$ & $\begin{array}{l}\text { Community-based cohort } \\
\text { study: } 363,426 \text { participants, } \\
\text { after excluding those with } \\
\text { cancer at baseline. Mean } \\
\text { follow-up: } 8.5 \text { years }\end{array}$ & Self-reported & $\begin{array}{l}\text { Age, sex, center, education } \\
\text { level, smoking, alcohol intake, } \\
\text { BMI, waist-to-height ratio }\end{array}$ & $\begin{array}{c}\text { DM was independently } \\
\text { associated with higher risk } \\
\text { of incident HCC and biliary } \\
\text { tract cancer. HCC risk was } \\
\text { higher in those treated with } \\
\text { insulin. Results were similar } \\
\text { in HCV/HBV-negative } \\
\text { individuals }\end{array}$ \\
\hline $\begin{array}{l}\text { Zheng et al., PLoS One } \\
\text { 2013; 8:e84776 }\end{array}$ & $\begin{array}{l}\text { Hospital-based retrospective } \\
\text { case-control study: } 1,568 \\
\text { participants of whom } 716 \\
\text { patients were diagnosed } \\
\text { with benign liver diseases } \\
\text { and } 852 \text { patients were } \\
\text { diagnosed with HCC. The } \\
\text { prevalence of DM was } 7.6 \%\end{array}$ & $\begin{array}{l}\text { Fasting glucose } \\
\geq 126 \mathrm{mg} / \mathrm{dL} \text { or } 2- \\
\text { hour postload } \\
\text { glucose } \geq 200 \mathrm{mg} / \mathrm{dL}, \\
\text { HbA } 1 \mathrm{c} \geq 6.5 \%\end{array}$ & $\begin{array}{l}\text { Age, sex, HBV and HCV } \\
\text { infections, cirrhosis, gallstone } \\
\text { disease, cholinesterase, } \\
\text { alkaline phosphatase }\end{array}$ & $\begin{array}{l}\text { DM was associated with } \\
\text { increased risk of HCC. } \\
\text { However, there was a } \\
\text { significant interaction } \\
\text { between DM and HBV on } \\
\text { HCC occurrence }\end{array}$ \\
\hline $\begin{array}{l}\text { Koh et al., Br J Cancer } \\
2013 ; 108: 1182-8\end{array}$ & $\begin{array}{l}\text { Community-based cohort } \\
\text { study: } 63,257 \text { middle-aged } \\
\text { and older individuals. The } \\
\text { prevalence of DM was } 8.6 \% \text {. } \\
\text { Mean follow-up: } 14 \text { years }\end{array}$ & Self-reported & $\begin{array}{c}\text { Age, sex, BMI, recruitment } \\
\text { year, education level, } \\
\text { smoking, alcohol intake, } \\
\text { consumption of coffee and tea }\end{array}$ & $\begin{array}{c}\text { DM was associated with an } \\
\text { increased risk of incident } \\
\text { nonviral HCC }\end{array}$ \\
\hline $\begin{array}{l}\text { Miele et al., } \\
\text { Gastroenterol Res } \\
\text { Pract 2015; 2015: } \\
570356\end{array}$ & $\begin{array}{c}\text { Hospital-based case-control } \\
\text { study: } 224 \text { HCC patients and } \\
389 \text { controls. The prevalence } \\
\text { of DM was } 19.7 \%\end{array}$ & Self-reported & $\begin{array}{l}\text { Age, sex, smoking, alcohol } \\
\text { intake }\end{array}$ & $\begin{array}{l}\text { DM was associated with } \\
\text { increased risk of HCC. } \\
\text { Treatment with any } \\
\text { glucose-lowering drugs was } \\
\text { not associated with } \\
\text { increased HCC risk }\end{array}$ \\
\hline $\begin{array}{l}\text { Adami et al., J Natl } \\
\text { Cancer Inst 1996; } 88 \text { : } \\
1472-7\end{array}$ & $\begin{array}{c}\text { Hospital-based cohort: } \\
\text { 153,852 patients with DM. } \\
\text { Follow-up: from } 1 \text { to } 24 \\
\text { years }\end{array}$ & $\begin{array}{l}\text { Hospital discharge } \\
\text { diagnosis }\end{array}$ & None & $\begin{array}{c}\mathrm{DM} \text { was associated with } \\
\text { increased risk of incident } \\
\text { HCC }\end{array}$ \\
\hline $\begin{array}{l}\text { La Vecchia et al., Int J } \\
\text { Cancer 1997; } 73: 204- \\
7\end{array}$ & $\begin{array}{l}\text { Case-control study: } 428 \\
\text { HCC cases, } 59 \text { with } \\
\text { gallbladder and bile duct } \\
\text { cancers, and 1,502 control } \\
\text { subjects from hospital }\end{array}$ & Self-reported & $\begin{array}{l}\text { Age, sex, area of residence, } \\
\text { education level, alcohol } \\
\text { intake, BMI, smoking, history } \\
\text { of chronic hepatitis and } \\
\text { cirrhosis, family history of } \\
\text { liver cancer }\end{array}$ & $\begin{array}{c}\mathrm{DM} \text { was associated with } \\
\text { increased risk of incident } \\
\text { HCC }\end{array}$ \\
\hline
\end{tabular}

uncontrolled type 2 diabetes [10]. In areas with high incidence, $80 \%$ of HCC patients test positive for hepatitis B surface antigen (HBsAg) in serum [72]. Moreover, 10-20\% of patients with hepatitis B can develop HCC without cirrhosis [73]. Hepatitis $\mathrm{C}$ virus (HCV) infection is also a major risk factor for HCC, which leads to a 5- to 20-fold risk of HCC [74]. Indeed, persistent cellular stress, repeated necrosis, and compensatory regeneration of cells, as well as chronic inflammation, lead to cellular senescence and mutagenesis, ultimately leading to hepatocarcinogenesis [75]. The mechanism of NAFLD-induced HCC is not fully understood, and there is no way to prevent NAFLD patients from progressing to HCC [76]. T2DM is a risk factor for NAFLD and increases HCC incidence two- to threefold [77]. NAFLD HCC patients have increased levels of IL-13, which can activate myeloid-derived suppressor cells and promote tumor progression by suppressing tumor immunity [78]. Another mechanism underlying NAFLD HCC is PNPLA3 gene polymorphism, possibly related to by enhancing inflammatory signaling [79]. Table 1 compiles the principal observational investigations and meta-analyses analyzing the association between T2DM and the risk of HCC.

\section{TCM Syndrome Types of T2DM with NAFLD}

In recent years, TCM and its extracts have been considered a new potential source of therapeutic drugs for preventing and treating fatty liver disease [80]. According to modern TCM theory, type 2 diabetes belongs to the category of diabetes. There are many problems, such as dryness and heat injury, qi and yin deficiency, liver qi and yin deficiency, liver failure, spleen failure, liver blood deficiency, and spleen stomach heat accumulation. Therefore, it can be divided into eight types: stomach heat syndrome, lung dryness syndrome, spleen qi deficiency syndrome, lung qi deficiency syndrome, yin and yang deficiency syndrome, kidney yin deficiency syndrome, blood stasis syndrome, and phlegm retention syndrome.

Statistical analysis showed that spleen deficiency syndrome was the main syndrome type in T2DM with the 


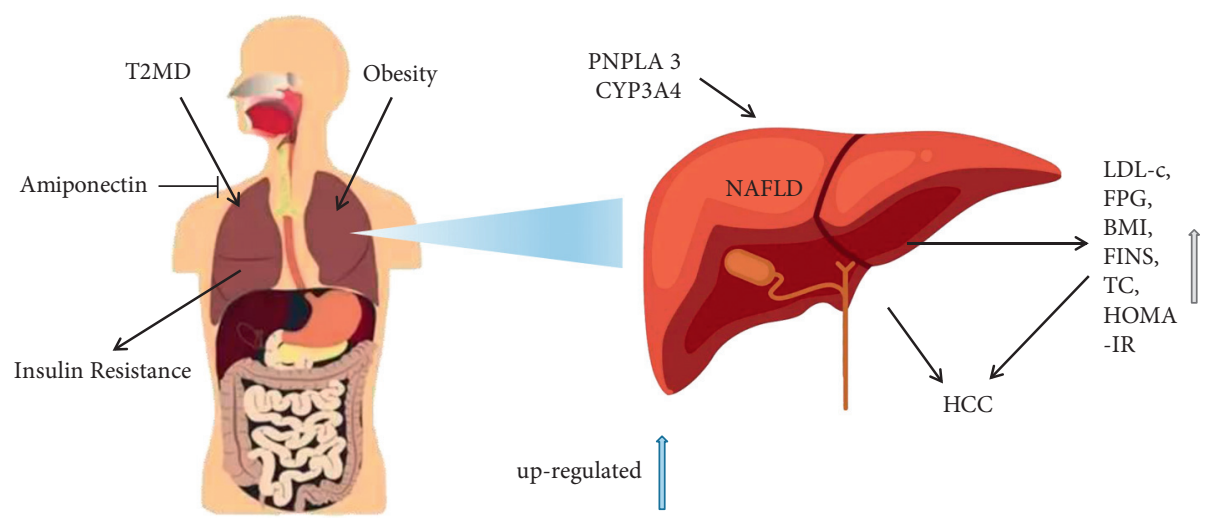

FIgUre 1: Biological mechanisms linking type 2 diabetes mellitus and NAFLD.

NAFLD group [81]. This has also been confirmed in other studies, and phlegm is one of the main syndrome characteristics [82]. There are also studies suggesting that, in T2DM patients with NAFLD, the proportion of damp-heat accumulation is the highest, followed by yin deficiency heat [83]. Additionally, studies also found that damp-heat trapped spleen syndrome and qi and yin deficiency syndrome are the most important syndrome types [84]. Correct evaluation of TCM syndrome types is helpful to improve the clinical effect of TCM combined with general therapy in the treatment of T2DM with NAFLD.

\section{Conclusion and Future Prospect}

At present, T2DM with NAFLD is considered as a multifactorial disease with genetic and environmental factors. IR is considered as a key risk factor for the occurrence and development of T2DM with NAFLD. IR in the peripheral tissue and liver is one of the causes of this condition, leading to the increase of circulating glucose and lipid substrates for lipid accumulation in the liver. Changing diet structure is beneficial to delay the progression of T2DM with NAFLD. It supports more extensive application of traditional Chinese medicine, Chinese patent medicine, and acupuncture physiotherapy, which provides theoretical support for the clinical application of traditional Chinese medicine therapy. However, there are still many deficiencies in the treatment of TCM. Therefore, further research and clinical verification are needed (Figure 1).

Prevention and treatment of viral hepatitis and NAFLD were vital factors in reducing the global burden of liver cancer. Implementation of screening for viral hepatitis and surveillance for hepatocellular carcinoma in high-risk patients are essential to improve current poor outcomes for patients with HCC. However, a better understanding of risk factors for liver cancer is required for developing new effective regimens and improving the efficacy of the existing therapies. [85]

\section{Conflicts of Interest}

The authors declare that they have no conflicts of interest.

\section{Authors' Contributions}

Yueying Qi and Decong Ran have contributed equally to this work.

\section{Acknowledgments}

This work was supported by the Research Project of Hebei Administration of Traditional Chinese Medicine (no. 2018479) and Project Support of Yuansong Wang Heritage Studio of Famous Traditional Chinese Medicine in Hebei Province.

\section{References}

[1] L. A. Adams, Q. M. Anstee, H. Tilg, and G. Targher, "Nonalcoholic fatty liver disease and its relationship with cardiovascular disease and other extrahepatic diseases," Gut, vol. 66, no. 6, pp. 1138-1153, 2017.

[2] S. Chitturi, V. W.-S. Wong, and G. Farrell, "Nonalcoholic fatty liver in Asia: firmly entrenched and rapidly gaining ground," Journal of Gastroenterology and Hepatology, vol. 26, no. 1, pp. 163-172, 2011.

[3] N. C. Leite, C. A. Villela-Nogueira, C. R. Cardoso, and G. F. Salles, "Non-alcoholic fatty liver disease and diabetes: from physiopathological interplay to diagnosis and treatment," World Journal of Gastroenterology, vol. 20, no. 26, pp. 8377-8392, 2014.

[4] T. Higashi, S. L. Friedman, and Y. Hoshida, "Hepatic stellate cells as key target in liver fibrosis," Advanced Drug Delivery Reviews, vol. 121, pp. 27-42, 2017.

[5] Z. M. Younossi, T. Gramlich, C. A. Matteoni, N. Boparai, and A. J. McCullough, "Nonalcoholic fatty liver disease in patients with type 2 diabetes," Clinical Gastroenterology and Hepatology, vol. 2, no. 3, pp. 262-265, 2004.

[6] L. Porepa, J. G. Ray, P. Sanchez-Romeu, and G. L. Booth, "Newly diagnosed diabetes mellitus as a risk factor for serious liver disease," Canadian Medical Association Journal, vol. 182, no. 11, pp. E526-E531, 2010.

[7] G. Musso, R. Gambino, M. Cassader, and G. Pagano, "Metaanalysis: natural history of non-alcoholic fatty liver disease (NAFLD) and diagnostic accuracy of non-invasive tests for liver disease severity," Annals of Medicine, vol. 43, no. 8, pp. 617-649, 2011.

[8] N. C. Leite, G. F. Salles, A. L. E. Araujo, C. A. Villela-Nogueira, and C. R. L. Cardoso, "Prevalence and associated factors of 
non-alcoholic fatty liver disease in patients with type-2 diabetes mellitus," Liver International, vol. 29, no. 1, pp. 113-119, 2009.

[9] M. Ekstedt, L. E. Franzén, U. L. Mathiesen et al., "Long-term follow-up of patients with NAFLD and elevated liver enzymes," Hepatology, vol. 44, no. 4, pp. 865-873, 2006.

[10] J. D. Yang, P. Hainaut, G. J. Gores, A. Amadou, A. Plymoth, and L. R. Roberts, "A global view of hepatocellular carcinoma: trends, risk, prevention and management," Nature Reviews Gastroenterology \& Hepatology, vol. 16, no. 10, pp. 589-604, 2019.

[11] J. D. Yang, H. A. Mohamed, J. L. Cvinar, G. J. Gores, L. R. Roberts, and R. W. Kim, "Diabetes mellitus heightens the risk of hepatocellular carcinoma except in patients with hepatitis C cirrhosis," American Journal of Gastroenterology, vol. 111, no. 11, pp. 1573-1580, 2016.

[12] B. E. Wang, "Treatment of chronic liver diseases with traditional Chinese medicine," Journal of Gastroenterology and Hepatology, vol. 15, pp. E67-E70, 2000

[13] M. Inoue, A. Hayashi, T. Taguchi et al., "Effects of canagliflozin on body composition and hepatic fat content in type 2 diabetes patients with non-alcoholic fatty liver disease," Journal of Diabetes Investigation, vol. 10, no. 4, pp. 1004-1011, 2019.

[14] Y. Ren, M. Zhang, J. Zhao et al., "Association of the hypertriglyceridemic waist phenotype and type 2 diabetes mellitus among adults in China," Journal of Diabetes Investigation, vol. 7, no. 5, pp. 689-694, 2016.

[15] Y. Xu, L. Wang, J. He et al., "Prevalence and control of diabetes in Chinese adults," Journal of the American Medical Association, vol. 310, no. 9, pp. 948-959, 2013.

[16] O. O. Oguntibeju, "Type 2 diabetes mellitus, oxidative stress and inflammation: examining the links," International journal of physiology, pathophysiology and pharmacology, vol. 11, no. 3, pp. 45-63, 2019.

[17] A. Bashier, A. Bin Hussain, E. Abdelgadir, F. Alawadi, H. Sabbour, and R. Chilton, "Consensus recommendations for management of patients with type 2 diabetes mellitus and cardiovascular diseases," Diabetology \& Metabolic Syndrome, vol. 11, no. 1, p. 80, 2019.

[18] G. Roglic, "Diabetes in women: the global perspective," International Journal of Gynaecology \& Obstetrics, vol. 104, pp. S11-S13, 2009.

[19] M. Silink, "Childhood diabetes: a global perspective," Hormone Research, vol. 57, no. Suppl 1, pp. 1-5, 2002.

[20] G. Moulis, B. Ibañez, A. Palmaro et al., "Cross-national health care database utilization between Spain and France: results from the EPICHRONIC study assessing the prevalence of type 2 diabetes mellitus," Clinical Epidemiology, vol. 10, pp. 863874, 2018.

[21] Z. M. Younossi, A. B. Koenig, D. Abdelatif, Y. Fazel, L. Henry, and M. Wymer, "Global epidemiology of nonalcoholic fatty liver disease-Meta-analytic assessment of prevalence, incidence, and outcomes," Hepatology, vol. 64, no. 1, pp. 73-84, 2016.

[22] M. W. Fleischman, M. Budoff, I. Zeb, D. Li, and T. Foster, "NAFLD prevalence differs among hispanic subgroups: the Multi-Ethnic Study of Atherosclerosis," World Journal of Gastroenterology, vol. 20, no. 17, pp. 4987-4993, 2014.

[23] Z. Li, J. Xue, P. Chen, L. Chen, S. Yan, and L. Liu, "Prevalence of nonalcoholic fatty liver disease in mainland of China: a meta-analysis of published studies," Journal of Gastroenterology and Hepatology, vol. 29, no. 1, pp. 42-51, 2014.
[24] L. Calzadilla Bertot and L. A. Adams, "The natural course of non-alcoholic fatty liver disease," International Journal of Molecular Sciences, vol. 17, no. 5, 2016.

[25] F. De Chiara, C. Ureta Checcllo, and J. Ramon Azcon, "High protein diet and metabolic plasticity in non-alcoholic fatty liver disease: myths and truths," Nutrients, vol. 11, no. 12, 2019.

[26] H. B. El-Serag and K. L. Rudolph, "Hepatocellular carcinoma: epidemiology and molecular carcinogenesis," Gastroenterology, vol. 132, no. 7, pp. 2557-2576, 2007.

[27] S. K. Sarin, M. Kumar, M. Eslam et al., "Liver diseases in the asia-pacific region: a lancet gastroenterology and hepatology commission," The Lancet Gastroenterology and Hepatology, vol. 5, no. 2, pp. 167-228, 2020.

[28] C. Kole, N. Charalampakis, S. Tsakatikas et al., "Immunotherapy for hepatocellular carcinoma: a 2021 update," Cancers, vol. 12, no. 10, 2020.

[29] Z. Chen, H. Xie, M. Hu et al., "Recent progress in treatment of hepatocellular carcinoma," American journal of cancer research, vol. 10, no. 9, pp. 2993-3036, 2020.

[30] S. Li, A. Saviano, D. J. Erstad et al., "Risk factors, pathogenesis, and strategies for hepatocellular carcinoma prevention: emphasis on secondary prevention and its translational challenges," Journal of Clinical Medicine, vol. 9, no. 12, 2020.

[31] Y.-L. Liu, H. L. Reeves, A. D. Burt et al., “TM6SF2 rs58542926 influences hepatic fibrosis progression in patients with nonalcoholic fatty liver disease," Nature Communications, vol. 5, no. 1, p. 4309, 2014.

[32] E. Smagris, S. Gilyard, S. BasuRay, J. C. Cohen, and H. H. Hobbs, "Inactivation of Tm6sf2, a gene defective in fatty liver disease, impairs lipidation but not secretion of very low density lipoproteins," Journal of Biological Chemistry, vol. 291, no. 20, pp. 10659-10676, 2016.

[33] Y. Zhou, G. Llauradó, M. Orešič, T. Hyötyläinen, M. OrhoMelander, and H. Yki-Järvinen, "Circulating triacylglycerol signatures and insulin sensitivity in NAFLD associated with the E167K variant in TM6SF2," Journal of Hepatology, vol. 62, no. 3, pp. 657-663, 2015.

[34] S. Romeo, J. Kozlitina, C. Xing et al., "Genetic variation in PNPLA3 confers susceptibility to nonalcoholic fatty liver disease," Nature Genetics, vol. 40, no. 12, pp. 1461-1465, 2008.

[35] P. Dongiovanni, S. Stender, A. Pietrelli et al., "Causal relationship of hepatic fat with liver damage and insulin resistance in nonalcoholic fatty liver," Journal of Internal Medicine, vol. 283, no. 4, pp. 356-370, 2018.

[36] Y. Huang, S. He, J. Z. Li et al., "A feed-forward loop amplifies nutritional regulation of PNPLA3," Proceedings of the National Academy of Sciences, vol. 107, no. 17, pp. 7892-7897, 2010.

[37] P.-W. Wang, C.-J. Hsieh, L.-C. Psang et al., "Fatty liver and chronic inflammation in Chinese adults," Diabetes Research and Clinical Practice, vol. 81, no. 2, pp. 202-208, 2008.

[38] C.-J. Hsieh, P. W. Wang, and T. H. Hu, "Association of adiponectin gene polymorphism with nonalcoholic fatty liver disease in Taiwanese patients with type 2 diabetes," PloS One, vol. 10, no. 6, Article ID e0127521, 2015.

[39] Z. L. Wang, B. Xia, U. Shrestha et al., "Correlation between adiponectin polymorphisms and non-alcoholic fatty liver disease with or without metabolic syndrome in Chinese population," Journal of Endocrinological Investigation, vol. 31, no. 12, pp. 1086-1091, 2008.

[40] M. Hashemi, H. Hanafi Bojd, E. Eskandari Nasab et al., "Association of adiponectin rs1501299 and rs266729 gene 
polymorphisms with nonalcoholic fatty liver disease," Hepatitis Monthly, vol. 13, no. 5, Article ID e9527, 2013.

[41] K. Tokushige, E. Hashimoto, H. Noto et al., "Influence of adiponectin gene polymorphisms in Japanese patients with non-alcoholic fatty liver disease," Journal of Gastroenterology, vol. 44, no. 9, pp. 976-982, 2009.

[42] N. C. Leite, G. F. Salles, C. R. L. Cardoso, and C. A. VillelaNogueira, "Serum biomarkers in type 2 diabetic patients with non-alcoholic steatohepatitis and advanced fibrosis," Hepatology Research, vol. 43, no. 5, pp. 508-515, 2013.

[43] H. Lu, J. Sun, L. Sun, X. Shu, Y. Xu, and D. Xie, "Polymorphism of human leptin receptor gene is associated with type 2 diabetic patients complicated with non-alcoholic fatty liver disease in China," Journal of Gastroenterology and Hepatology, vol. 24, no. 2, pp. 228-232, 2009.

[44] Z. Zhang, J. Wang, and H. Wang, "Correlation of blood glucose, serum chemerin and insulin resistance with NAFLD in patients with type 2 diabetes mellitus," Experimental and therapeutic medicine, vol. 15, no. 3, pp. 2936-2940, 2018.

[45] U. Jung and M.-S. Choi, "Obesity and its metabolic complications: the role of adipokines and the relationship between obesity, inflammation, insulin resistance, dyslipidemia and nonalcoholic fatty liver disease," International Journal of Molecular Sciences, vol. 15, no. 4, pp. 6184-6223, 2014.

[46] C. P. Day and O. F. W. James, "Steatohepatitis: a tale of two "hits"?" Gastroenterology, vol. 114, no. 4, pp. 842-845, 1998.

[47] G. Targher, C. P. Day, and E. Bonora, "Risk of cardiovascular disease in patients with nonalcoholic fatty liver disease," New England Journal of Medicine, vol. 363, no. 14, pp. 1341-1350, 2010.

[48] I. C. M. Simoes, J. Janikiewicz, J. Bauer et al., "Fat and sugar-A dangerous duet. A comparative review on metabolic remodeling in rodent models of nonalcoholic fatty liver disease," Nutrients, vol. 11, no. 12, 2019.

[49] S. E. Shoelson, L. Herrero, and A. Naaz, "Obesity, inflammation, and insulin resistance," Gastroenterology, vol. 132, no. 6, pp. 2169-2180, 2007.

[50] Y. Arase, K. Shiraishi, K. Anzai et al., "Effect of sodium glucose Co-transporter 2 inhibitors on liver fat mass and body composition in patients with nonalcoholic fatty liver disease and type 2 diabetes mellitus," Clinical Drug Investigation, vol. 39, no. 7, pp. 631-641, 2019.

[51] M. Lazo, S. F. Solga, A. Horska et al., "Effect of a 12-month intensive lifestyle intervention on hepatic steatosis in adults with type 2 diabetes," Diabetes Care, vol. 33, no. 10, pp. $2156-2163,2010$.

[52] V. W.-S. Wong, G. L.-H. Wong, R. S.-M. Chan et al., "Beneficial effects of lifestyle intervention in non-obese patients with non-alcoholic fatty liver disease," Journal of Hepatology, vol. 69, no. 6, pp. 1349-1356, 2018.

[53] S. M. Grundy, N. Abate, and M. Chandalia, "Diet composition and the metabolic syndrome: what is the optimal fat intake?" Americas Journal of Medicine, vol. 113, no. Suppl 9B, pp. 25S-9S, 2002.

[54] M. J. Saez-Lara, C. Robles-Sanchez, F. J. Ruiz-Ojeda, J. PlazaDiaz, and A. Gil, "Effects of probiotics and synbiotics on obesity, insulin resistance syndrome, type 2 diabetes and nonalcoholic fatty liver disease: a review of human clinical trials," International Journal of Molecular Sciences, vol. 17, no. 6, 2016.

[55] M. T. Hamilton, D. G. Hamilton, and T. W. Zderic, "Role of low energy expenditure and sitting in obesity, metabolic syndrome, type 2 diabetes, and cardiovascular disease," Diabetes, vol. 56, no. 11, pp. 2655-2667, 2007.
[56] B. Wang, X.-L. Mu, J. Zhao et al., "Effects of lifestyle interventions on rural patients with type 2 diabetes mellitus," World Journal of Diabetes, vol. 11, no. 6, pp. 261-268, 2020.

[57] N. J. Snowling and W. G. Hopkins, "Effects of different modes of exercise training on glucose control and risk factors for complications in type 2 diabetic patients: a meta-analysis," Diabetes Care, vol. 29, no. 11, pp. 2518-2527, 2006.

[58] S. Ryu, Y. Chang, H.-S. Jung et al., "Relationship of sitting time and physical activity with non-alcoholic fatty liver disease," Journal of Hepatology, vol. 63, no. 5, pp. 1229-1237, 2015.

[59] E. Hui, A. Xu, H. Bo Yang, and K. S. L. Lam, "Obesity as the common soil of non-alcoholic fatty liver disease and diabetes: role of adipokines," Journal of Diabetes Investigation, vol. 4, no. 5, pp. 413-425, 2013.

[60] B. J. Maliakkal, "Pathogenesis of non-alcoholic fatty liver disease and implications on cardiovascular outcomes in liver transplantation," Translational Gastroenterology and Hepatology, vol. 5, p. 36, 2020.

[61] G. Firneisz, "Non-alcoholic fatty liver disease and type 2 diabetes mellitus: the liver disease of our age?" World Journal of Gastroenterology, vol. 20, no. 27, pp. 9072-9089, 2014.

[62] H. Tilg and A. R. Moschen, "Evolution of inflammation in nonalcoholic fatty liver disease: the multiple parallel hits hypothesis," Hepatology, vol. 52, no. 5, pp. 1836-1846, 2010.

[63] C. M. Perdomo, G. Frühbeck, and J. Escalada, "Impact of nutritional changes on nonalcoholic fatty liver disease," Nutrients, vol. 11, no. 3, 2019.

[64] J. M. Hazlehurst, C. Woods, T. Marjot, J. F. Cobbold, and J. W. Tomlinson, "Non-alcoholic fatty liver disease and diabetes," Metabolism, vol. 65, no. 8, pp. 1096-1108, 2016.

[65] S. Duranti, C. Ferrario, D. van Sinderen, M. Ventura, and F. Turroni, "Obesity and microbiota: an example of an intricate relationship," Genes \& Nutrition, vol. 12, no. 1, p. 18, 2017.

[66] R. Jamwal, S. M. de la Monte, K. Ogasawara, S. Adusumalli, B. B. Barlock, and F. Akhlaghi, "Nonalcoholic fatty liver disease and diabetes are associated with decreased CYP3A4 protein expression and activity in human liver," Molecular Pharmaceutics, vol. 15, no. 7, pp. 2621-2632, 2018.

[67] L. Marino and F. R. Jornayvaz, "Endocrine causes of nonalcoholic fatty liver disease," World Journal of Gastroenterology, vol. 21, no. 39, pp. 11053-11076, 2015.

[68] A. S. Butt, S. Hamid, Z. Haider et al., "Nonalcoholic fatty liver diseases among recently diagnosed patients with diabetes mellitus and risk factors," Euroasian Journal of HepatoGastroenterology, vol. 9, no. 1, pp. 9-13, 2019.

[69] D. Pitocco, M. Di Leo, L. Tartaglione et al., "The role of gut microbiota in mediating obesity and diabetes mellitus," European Review for Medical and Pharmacological Sciences, vol. 24, no. 3, pp. 1548-1562, 2020.

[70] K. Mokkala, N. Houttu, T. Cansev, and K. Laitinen, "Interactions of dietary fat with the gut microbiota: evaluation of mechanisms and metabolic consequences," Clinical Nutrition, vol. 39, no. 4, pp. 994-1018, 2020.

[71] Y. Ji, Y. Yin, L. Sun, and W. Zhang, "The molecular and mechanistic insights based on gut-liver Axis: nutritional target for non-alcoholic fatty liver disease (NAFLD) improvement," International Journal of Molecular Sciences, vol. 21, no. 9, 2020.

[72] Y.-S. Hsu, R.-N. Chien, C.-T. Yeh et al., "Long-term outcome after spontaneous $\mathrm{HBeAg}$ seroconversion in patients with chronic hepatitis B," Hepatology, vol. 35, no. 6, pp. 1522-1527, 2002. 
[73] J. D. Yang, W. R. Kim, R. Coelho et al., "Cirrhosis is present in most patients with hepatitis B and hepatocellular carcinoma," Clinical Gastroenterology and Hepatology, vol. 9, no. 1, pp. 64-70, 2011.

[74] S. Dash, Y. Aydin, K. E. Widmer, and L. Nayak, "Hepatocellular carcinoma mechanisms associated with chronic HCV infection and the impact of direct-acting antiviral treatment," Journal of Hepatocellular Carcinoma, vol. 7, pp. 45-76, 2020.

[75] J. Giraud, D. Chalopin, J.-F. Blanc, and M. Saleh, "Hepatocellular carcinoma immune landscape and the potential of immunotherapies," Frontiers in Immunology, vol. 12, Article ID 655697, 2021.

[76] N. Fujiwara, S. L. Friedman, N. Goossens, and Y. Hoshida, "Risk factors and prevention of hepatocellular carcinoma in the era of precision medicine," Journal of Hepatology, vol. 68, no. 3, pp. 526-549, 2018.

[77] N. N. Massarweh and H. B. El-Serag, "Epidemiology of hepatocellular carcinoma and intrahepatic cholangiocarcinoma," Cancer Control : Journal of the Moffitt Cancer Center, vol. 24, no. 3, Article ID 1073274817729245, 2017.

[78] F. R. Ponziani, S. Bhoori, C. Castelli et al., "Hepatocellular carcinoma is associated with gut microbiota profile and inflammation in nonalcoholic fatty liver disease," Hepatology, vol. 69, no. 1, pp. 107-120, 2019.

[79] K. Friedrich, A. Wannhoff, S. Kattner et al., "PNPLA3 in endstage liver disease: alcohol consumption, hepatocellular carcinoma development, and transplantation-free survival," Journal of Gastroenterology and Hepatology, vol. 29, no. 7, pp. 1477-1484, 2014.

[80] S. Panyod and L.-Y. Sheen, "Beneficial effects of Chinese herbs in the treatment of fatty liver diseases," Journal of Traditional and Complementary Medicine, vol. 10, no. 3, pp. 260-267, 2020.

[81] C. Li and J. Pang, "TCM clinical research progress of type 2 diabetes mellitus with nonalcoholic fatty liver disease," Mass technology, vol. 21, no. 02, pp. 61-64, 2019.

[82] X. Liu, Correlation Between TCM Syndrome Types and Islet $\beta$ Cell Function in Newly Diagnosed Type 2 Diabetes Mellitus Patients with Nonalcoholic Fatty Liver Disease, Traditional Chinese Medicine University of Gansu, Lanzhou, China, 2017.

[83] Z. Zhang, J. Wu, and Y. Qi, "Clinical study on main risk factors and TCM syndrome types of type 2 diabetes mellitus with nonalcoholic fatty liver disease," Modern distance education of traditional Chinese medicine in China, vol. 17, no. 11, pp. 48-50, 2019.

[84] Y. Lu, Analysis of the Difference and Risk Factors of Insulin Resistance in Different TCM Syndrome Types of Type 2 Diabetes Mellitus with Nonalcoholic Fatty Liver Disease, Chinese Medical University of Zhejiang, Hangzhou, China, 2013.

[85] T. Gao, L. Yan, and Y. Wang, "Analysis of common TCM syndromes and nonalcoholic fatty liver disease and related risk factors in newly diagnosed type 2 diabetes mellitus," Journal of Traditional Chinese Medicine in Liaoning, vol. 38, no. 02, pp. 200-202, 2011. 